\title{
UPAYA MENINGKATKAN PRESTASI DAN KUALITAS BELAJAR BAHASA INDONESIA PADA MATERI BERBICARA DAN MEMBACA DENGAN MENERAPKAN METODE STAD DAN METODE ROLE PLAYING PADA SISWA KELAS VI SDN SINTUNG TIMUR
}

\author{
Sri Rudiawati \\ Guru SDN Sintung Timur, srirudiawati@gmail.com
}

\begin{tabular}{|c|c|}
\hline INFO ARTIKEL & ABSTRAK \\
\hline Riwayat Artikel: & $\begin{array}{l}\text { Abstrak: Tujuan penelitian ini ingin mengetahui peningkatan prestasi belajar melalui } \\
\text { penerapan pembelajaran model STAD dan Role Playing terhadap siswa Kelas VI SDN }\end{array}$ \\
\hline a: 03-03-2018 & Sintung Timur Tahun Ajaran 2015/2016. Penelitian ini menggunakan penelitian \\
\hline Disetuju & $\begin{array}{l}\text { tindakan kelas tiga suiklus. Pengumpulan data berupa hasil tes formatif, lembar } \\
\text { observasi kegiatan belajar mengajar. Didapatkan bahwa prestasi belajar siswa } \\
\text { mengalami peningkatan dari siklus I sampai siklus III yaitu, siklus I }(68,18 \%) \text {, siklus II }\end{array}$ \\
\hline Kata Kunci: & $\begin{array}{l}\text { (77,27\%), siklus III }(86,36 \%) \text {. Kesimpulan bahwa penerapan model STAD dan Role } \\
\text { Plaving dapat meningkatkan prestasi belajar Siswa kelas VI SDN Sintung Timur }\end{array}$ \\
\hline esia, & Tahun Ajaran 2015/2016. \\
\hline
\end{tabular}

Model STAD dan

Role Playing

\begin{abstract}
The purpose of this study would like to know the improvement of learning achievement through the application of STAD and Role Playing model learning to the students of Class VI SDN Sintung Timur in School Year 2015/2016. This study used a classroom action research of three cycles. Data collection in the form of formative test result, observation sheet of teaching and learning activities. It was found that students' learning achievement increased from cycle I to cycle III that is, cycle I (68,18\%), cycle II (77,27\%), cycle III (86,36\%). The conclusion that the application of STAD and Role Playing model can improve the learning achievement of grade 6 students of SDN Sintung Timur in the academic year 2015/2016.
\end{abstract}

\section{A. LATAR BELAKANG}

Pada pembelajaran Bahasa Indonesia di tingkat sekolah dasar / madrasah ibtidaiyah sangat mengandalkan penggunaan metode-metode yang aplikatif dan menarik. Pembelajaran yang menarik akan memikat anak-anak untuk terus dan betah mempelajari Bahasa Indonesia sebagai bahasa ke-2 setelah bahasa ibu. Apabila siswa sudah tertarik dengan pembelajaran maka akan dengan mudah meningkatkan prestasi siswa dalam bidang bahasa. Di sebagian siswa, pembelajaran Bahasa Indonesia sangat membosankan karena mereka sudah merasa bisa dan penyampaian materi yang kurang menarik sehingga secara tidak langsung siswa menjadi lemah dalam penangkapan materi tersebut. Penulis sebagai guru Bahasa Indonesia sangat merasakan problem pembelajaran yang terjadi selama ini.

Penulis juga menemui kasus serupa ketika berada di daerah kabupaten yang terpencil sangat kurang sekali penggunaan Bahasa Indonesia yang baik dan benar. Oleh sebab itu, penulis berusaha melakukan perubahanperubahan dalam pembelajaran Bahasa Indonesia di dalam kelas. Salah satu perubahan yang dilakukan dengan menggunakan metode Role Playing dan metode STAD (student teams achievement division) dalam standart kompetensi berbicara dan membaca. Dalam pembelajaran Menceritakan Kegemaran, dapat dilakukan dengan menggunakan metode role play sehingga menjadikan siswa lebih aktif. Metode role play memahami bahasa sebagai keterampilan berbicara secara langsung dengan berdasarkan kehidupan siswa dalam masayarakat. Metode role play sangat cocok diterapkan ketika pengajar melakukan pembelajaran berbicara dengan dibantu dengan kartu peran.

Dalam pembelajaran membaca dapat memakai metode STAD sebagai kegiatan memacu anak-anak memahami bacaan dengan cara diskusi kelompok. Teori STAD (student teams achievement division) merupakan metode yang menekankan kepada kerja sama kelompok untuk menyelesaikan sebuah masalah. Dalam metode ini, siswa ditempatkan dalam tim belajar beranggotakan empat atau lima orang yang merupakan campuran menurut tingkat prestasi, jenis kelamin, dan suku. Guru menyajikan pelajaran, siswa bekerja dalam tim mereka untuk memastikan seluruh anggota tim telah menguasai pelajaran tersebut. Saat belajar berkelompok, siswa saling 
membantu untuk menuntaskan materi yang dipelajari. Guru memantau dan mengelilingi tiap kelompok untuk melihat adanya kemungkinan siswa yang memerlukan bantuan guru. Metode ini pun dibantu oleh metode pelatihan, penugasan, dan tanya jawab sesuai satuan pelajaran sehingga ketuntasan materi dapat terwujud (Her World Indonesia edisi Maret 2005, halaman 190 - 1).

Berdasarkan uraian di atas, judul yang diambil oleh peneliti dalam penelitian ini adalah Upaya Meningkatkan Prestasi Dan Kualitas Belajar bahasa Indonesia Pada Materi Berbicara dan Membaca Dengan Menerapkan Metode STAD dan Metode Role Playing Pada Siswa Kelas VI Tahun Pelajaran 2015/2016.

\section{B. METODE PENELITIAN}

\section{Rancangan Penelitian}

Penelitian ini menggunakan model penelitian tindakan dari Kemmis dan Taggart (dalam Sugiarti, 1997: 6), yaitu berbentuk spiral dari sklus yang satu ke siklus yang berikutnya. Setiap siklus meliputi planning (rencana), action (tindakan), observation (pengamatan), dan reflection (refleksi). Langkah pada siklus berikutnya adalah perncanaan yang sudah direvisi, tindakan, pengamatan, dan refleksi. Sebelum masuk pada siklus 1 dilakukan tindakan pendahuluan yang berupa identifikasi permasalahan. Siklus spiral dari tahap-tahap penelitian tindakan kelas dapat dilihat pada gambar berikut.

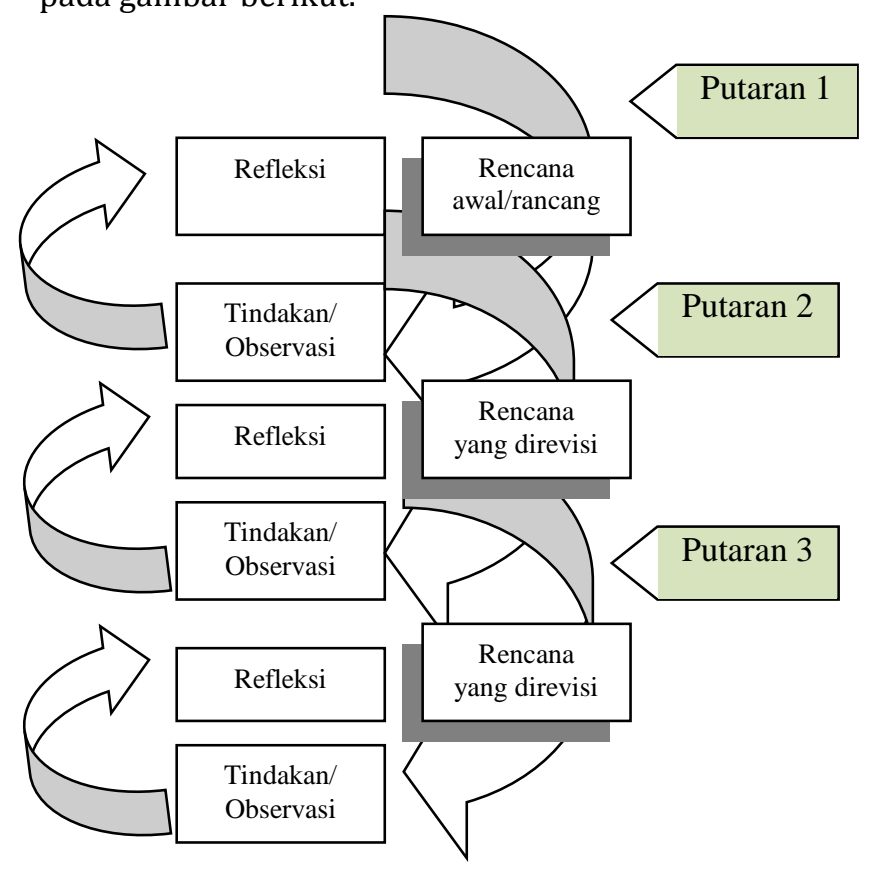

Gambar 1 Alur PTK

Penjelasan alur di atas adalah:

a. Rancangan/rencana awal, sebelum mengadakan penelitian peneliti menyusun rumusan masalah, tujuan dan membuat rencana tindakan, termasuk di dalamnya instrumen penelitian dan perangkat pembelajaran. b. Kegiatan dan pengamatan, meliputi tindakan yang dilakukan oleh peneliti sebagai upaya membangun pemahaman konsep siswa serta mengamati hasil atau dampak dari diterapkannya metode pembelajaran model discovery .

c. Refleksi, peneliti mengkaji, melihat dan mempertimbangkan hasil atau dampak dari tindakan yang dilakukan berdasarkan lembar pengamatan yang diisi oleh pengamat.

d. Rancangan/rencana yang direvisi, berdasarkan hasil refleksi dari pengamat membuat rancangan yang direvisi untuk dilaksanakan pada siklus berikutnya.

Observasi dibagi dalam tiga putaran, yaitu putaran 1, 2 dan 3, dimana masing putaran dikenai perlakuan yang sama (alur kegiatan yang sama) dan membahas satu sub pokok bahasan yang diakhiri dengan tes formatif di akhir masing putaran. Dibuat dalam tiga putaran dimaksudkan untuk memperbaiki sistem pengajaran yang telah dilaksanakan.

\section{Instrumen Penelitian}

Instrumen yang digunakan dalam penelitian ini terdiri dari:

a. Silabus, yaitu seperangkat rencana dan pengaturan tentang kegiatan pembelajaran pengelolahan kelas, serta penilaian hasil belajar.

b. Rencana Pelajaran (RP), yaitu merupakan perangkat pembelajaran yang digunakan sebagai pedoman guru dalam mengajar dan disusun untuk tiap putaran. Masing-masing RP berisi kompetensi dasar, indicator pencapaian hasil belajar, tujuan pembelajaran khusus, dan kegiatan belajar mengajar.

c. Lembar Kegiatan Siswa, Lembar kegaian ini yang dipergunakan siswa untuk membantu proses pengumpulan data hasil eksperimen.

d. Lembar Observasi Kegiatan Belajar Mengajar

1) Lembar observasi pengolahan pembelajaran model STAD dan Role Playing, untuk mengamati kemampuan guru dalam mengelola pembelajaran.

2) Lembar observasi aktivitas siswa dan guru, untuk mengamati aktivitas siswa dan guru selama proses pembelajaran.

e. Tes formatif. Tes ini disusun berdasarkan tujuan pembelajaran yang akan dicapai. Tes formatif ini diberikan setiap akhir putaran. Bentuk soal yang diberikan adalah pilihan ganda (objektif). Sebelumnya soal-soal ini berjumlah 46 


\section{Teknik Analisis Data}

Untuk mengalisis tingkat keberhasilan atau persentase keberhasilan siswa setelah proses belajar mengajar setiap putarannya dilakukan dengan cara memberikan evaluasi berupa soal tes tertulis pada setiap akhir putaran.

Analisis ini dihitung dengan menggunakan statistik sederhana yaitu:

a. Untuk menilai ulangan atu tes formatif

Peneliti melakukan penjumlahan nilai yang diperoleh siswa, yang selanjutnya dibagi dengan jumlah siswa yang ada di kelas tersebut sehingga diperoleh rata-rata tes formatif dapat dirumuskan:

$$
\bar{X}=\frac{\sum X}{\sum N}
$$

b. Untuk ketuntasan belajar

Ada dua kategori ketuntasan belajar yaitu secara perorangan dan secara klasikal. Berdasarkan petunjuk pelaksanaan belajar mengajar kurikulum 1994 (Depdikbud, 1994), yaitu seorang siswa telah tuntas belajar bila telah mencapai skor $65 \%$ atau nilai 65 , dan kelas disebut tuntas belajar bila di kelas tersebut terdapat $85 \%$ yang telah mencapai daya serap lebih dari sama dengan 65\%. Untuk menghitung persentase ketuntasan belajar digunakan rumus sebagai berikut:

$$
P=\frac{\sum \text { Siswa.Tuntas }}{\sum \text { Siswa }} \times 100 \%
$$

\section{HASIL DAN PEMBAHASAN}

1. Siklus I

\section{a. Tahap Perencanaan}

Pada tahap ini peneliti mempersiapkan perangkat pembelajaran yang terdiri dari rencana pelajaran 1, LKS 1 , soal tes formatif 1 , dan alat-alat pengajaran yang mendukung.

\section{b. Tahap Kegiatan dan Pelaksanaan}

Pelaksanaan kegiatan belajar mengajar untuk siklus I dilaksanakan pada tanggal 4 September 2016 di kelas VI dengan jumlah siswa 22 siswa. Dalam hal ini peneliti bertindak sebagai guru. Adapun proses belajar mengajar mengacu pada rencana pelajaran yang telah dipersiapkan. Pengamatan (observasi) dilaksanakan bersamaan dengan pelaksanaan belajar mengajar.

TABEL 1

REKAPITULASI HASIL TES SIKLUS I

\begin{tabular}{|c|l|c|}
\hline No & \multicolumn{1}{|c|}{ Uraian } & $\begin{array}{c}\text { Hasil } \\
\text { Siklus I }\end{array}$ \\
\hline 1 & Nilai rata-rata tes & 69,09 \\
2 & formatif & 15 \\
3 & Jumlah siswa yang & 68,18 \\
\hline
\end{tabular}

\begin{tabular}{|l|l|l|}
\hline & $\begin{array}{l}\text { tuntas belajar } \\
\text { Persentase } \\
\text { ketuntasan belajar }\end{array}$ & \\
\hline
\end{tabular}

Dari tabel di atas dapat dijelaskan bahwa dengan menerapkan metode pembelajaran model STAD dan Role Playing diperoleh nilai rata-rata prestasi belajar siswa adalah 69,09 dan ketuntasan belajar mencapai $68,18 \%$ atau ada 15 siswa dari 22 siswa sudah tuntas belajar. Hasil tersebut menunjukkan bahwa pada siklus pertama secara klasikal siswa belum tuntas belajar, karena siswa yang memperoleh nilai $\geq 65$ hanya sebesar $68,18 \%$ lebih kecil dari persentase ketuntasan yang dikehendaki yaitu sebesar 85\%. Hal ini disebabkan karena siswa masih merasa baru dan belum mengerti apa yang dimaksudkan dan digunakan guru dengan menerapkan metode pembelajaran model STAD dan Role Playing.

2. Siklus II

a. Tahap kegiatan dan pelaksanaan

Pelaksanaan kegiatan belajar mengajar untuk siklus II dilaksanakan pada tanggal 12 September 2016 di kelas VI dengan jumlah siswa 22 siswa. Dalam hal ini peneliti bertindak sebagai guru. Adapun proses belajar mengajar mengacu pada rencana pelajaran dengan memperhatikan revisi pada siklus I, sehingga kesalahan atau kekurangan pada siklus I tidak terulang lagi pada siklus II. Pengamatan (observasi) dilaksanakan bersamaan dengan pelaksanaan belajar mengajar.

Pada akhir proses belajar mengajar siswa diberi tes formatif II dengan tujuan untuk mengetahui tingkat keberhasilan siswa selama proses belajar mengajar yang telah dilakukan. Instrument yang digunakan adalah tes formatif II. Adapun data hasil penelitian pada siklus II adalah sebagai berikut.

\begin{tabular}{|c|c|c|}
\hline No & Uraian & $\begin{array}{c}\text { Hasil } \\
\text { Siklus II }\end{array}$ \\
\hline 1 & Nilai rata-rata & 76,36 \\
\hline 2 & formatif & 17 \\
\hline 3 & $\begin{array}{l}\text { Jumlah siswa yang } \\
\text { tuntas belajar } \\
\text { Persentase ketuntasan } \\
\text { belajar }\end{array}$ & 77,27 \\
\hline
\end{tabular}

TABEL 2

Dari tabel di atas diperoleh nilai rata-rata prestasi belajar siswa adalah 76,36 dan ketuntasan belajar mencapai 77,27\% atau ada 17 siswa dari 22 siswa sudah tuntas belajar. Hasil ini menunjukkan bahwa pada siklus II ini ketuntasan belajar secara klasikal telah megalami peningkatan sedikit lebih baik dari siklus I. 
Adanya peningkatan hasil belajar siswa ini karena setelah guru menginformasikan bahwa setiap akhir pelajaran akan selalu diadakan tes sehingga pada pertemuan berikutnya siswa lebih termotivasi untuk belajar. Selain itu siswa juga sudah mulai mengerti apa yang dimaksudkan dan diinginkan guru dengan menerapkan metode pembelajaran model STAD dan Role Playing.

3. Siklus III

\section{a. Tahap Perencanaan}

Pada tahap ini peneliti mempersiapkan perangkat pembelajaran yang terdiri dari rencana pelajaran 3 , LKS 3, soal tes formatif 3, dan alat-alat pengajaran yang mendukung

b. Tahap kegiatan dan pengamatan

Pelaksanaan kegiatan belajar mengajar untuk siklus III dilaksanakan pada tanggal 19 September 2016 di kelas VI dengan jumlah siswa 22 siswa. Dalam hal ini peneliti bertindak sebagai guru. Adapun proses belajar mengajar mengacu pada rencana pelajaran dengan memperhatikan revisi pada siklus II, sehingga kesalahan atau kekurangan pada siklus II tidak terulang lagi pada siklus III. Pengamatan (observasi) dilaksanakan bersamaan dengan pelaksanaan belajar mengajar.

Pada akhir proses belajar mengajar siswa diberi tes formatif III dengan tujuan untuk mengetahui tingkat keberhasilan siswa dalam proses belajar mengajar yang telah dilakukan. Instrumen yang digunakan adalah tes formatif III. Adapun data hasil peneitian pada siklus III adalah sebagai berikut:

TABEL 3

HASIL TES FORMATIF SISWA PADA SIKLUS III

\begin{tabular}{|c|c|c|c|c|c|c|c|}
\hline \multirow{2}{*}{ No. } & \multirow{2}{*}{ Nilai } & \multicolumn{2}{|c|}{$\begin{array}{c}\text { Keterang } \\
\text { an }\end{array}$} & \multirow{2}{*}{$\begin{array}{c}\text { No. } \\
\text { Uru } \\
\mathrm{t}\end{array}$} & \multirow{2}{*}{$\begin{array}{c}\text { Nila } \\
\text { i }\end{array}$} & \multicolumn{2}{|c|}{$\begin{array}{c}\text { Keterang } \\
\text { an }\end{array}$} \\
\hline & & $\mathrm{T}$ & $\begin{array}{l}\mathrm{T} \\
\mathrm{T}\end{array}$ & & & $\mathrm{T}$ & $\mathrm{TT}$ \\
\hline 1 & 90 & $\sqrt{ }$ & & 12 & 90 & $\sqrt{ }$ & \\
\hline 2 & 90 & $\sqrt{ }$ & & 13 & 90 & $\sqrt{ }$ & \\
\hline 3 & 90 & $\sqrt{ }$ & & 14 & 90 & $\sqrt{ }$ & \\
\hline 4 & 80 & $\sqrt{ }$ & & 15 & 60 & & $\sqrt{ }$ \\
\hline 5 & 90 & $\sqrt{ }$ & & 16 & 90 & $\sqrt{ }$ & \\
\hline 6 & 80 & $\sqrt{ }$ & & 17 & 80 & $\sqrt{ }$ & \\
\hline 7 & 90 & $\sqrt{ }$ & & 18 & 70 & $\sqrt{ }$ & \\
\hline 8 & 60 & & $\sqrt{ }$ & 19 & 70 & $\sqrt{ }$ & \\
\hline 9 & 90 & $\sqrt{ }$ & & 20 & 80 & $\sqrt{ }$ & \\
\hline 10 & 90 & $\sqrt{ }$ & & 21 & 90 & $\sqrt{ }$ & \\
\hline 11 & 60 & & $\sqrt{ }$ & 22 & 80 & $\sqrt{ }$ & \\
\hline Jum & 910 & 9 & 2 & $\begin{array}{l}\text { Jum } \\
\text { lah }\end{array}$ & 890 & $\begin{array}{l}1 \\
0 \\
\end{array}$ & 1 \\
\hline $\begin{array}{l}\text { Juml } \\
\text { Juml } \\
\text { Rata- }\end{array}$ & $\begin{array}{l}\text { Skor } 1 \\
\text { Skor } \\
\text { ta Sko }\end{array}$ & 0 & & 82 & & & \\
\hline
\end{tabular}

Keterangan:

$\mathrm{T}$

TT

: Tuntas

Jumlah siswa yang tuntas

: Tidak Tuntas

Jumlah siswa yang belum tuntas : 3

Klasikal

: Tuntas

TABEL 4

REKAPITULASI HASIL TES SIKLUS III

\begin{tabular}{|c|l|c|}
\hline No & \multicolumn{1}{|c|}{ Uraian } & $\begin{array}{c}\text { Hasil Siklus } \\
\text { III }\end{array}$ \\
\hline 1 & Nilai rata-rata tes & 81,82 \\
2 & formatif & 19 \\
3 & $\begin{array}{l}\text { Jumlah siswa yang } \\
\text { tuntas belajar } \\
\text { Persentase ketuntasan } \\
\text { belajar }\end{array}$ & \\
\hline
\end{tabular}

Berdasarkan tabel diatas diperoleh nilai ratarata tes formatif sebesar 81,82 dan dari 22 siswa yang telah tuntas sebanyak 19 siswa dan 3 siswa belum mencapai ketuntasan belajar. Maka secara klasikal ketuntasan belajar yang telah tercapai sebesar 86,36\% (termasuk kategori tuntas). Hasil pada siklus III ini mengalami peningkatan lebih baik dari siklus II. Adanya peningkatan hasil belajar pada siklus III ini dipengaruhi oleh adanya peningkatan kemampuan guru dalam menerapkan pembelajaran model STAD dan Role Playing sehingga siswa menjadi lebih terbiasa dengan pembelajaran seperti ini sehingga siswa lebih mudah dalam memahami materi yang telah diberikan. Pada siklus III ini ketuntasan secara klasikal telah tercapai, sehingga penelitian ini hanya sampai pada siklus III.

c. Refleksi

Pada tahap ini akah dikaji apa yang telah terlaksana dengan baik maupun yang masih kurang baik dalam proses belajar mengajar dengan penerapan pembelajaran model STAD dan Role Playing. Dari data-data yang telah diperoleh dapat duraikan sebagai berikut:

1) Selama proses belajar mengajar guru telah melaksanakan semua pembelajaran dengan baik. Meskipun ada beberapa aspek yang belum sempurna, tetapi persentase pelaksanaannya untuk masing-masing aspek cukup besar.

2) Berdasarkan data hasil pengamatan diketahui bahwa siswa aktif selama proses belajar berlangsung.

3) Kekurangan pada siklus-siklus sebelumnya sudah mengalami perbaikan dan peningkatan sehingga menjadi lebih baik.

4) Hasil belajar siswa pada siklus III mencapai ketuntasan. 


\section{Ketuntasan Hasil belajar Siswa}

Melalui hasil peneilitian ini menunjukkan bahwa pembelajaran model STAD dan Role Playing memiliki dampak positif dalam meningkatkan prestasi belajar siswa. Hal ini dapat dilihat dari semakin mantapnya pemahaman siswa terhadap materi yang disampaikan guru (ketuntasan belajar meningkat dari sklus I, II, dan II) yaitu masing-masing 68,18\%, 77,27\%, dan 86,36\%. Pada siklus III ketuntasan belajar siswa secara klasikal telah tercapai.

2. Kemampuan Guru dalam Mengelola Pembelajaran

Berdasarkan analisis data, diperoleh aktivitas siswa dalam proses pembelajaran model STAD dan Role Playing dalam setiap siklus mengalami peningkatan. Hal ini berdampak positif terhadap prestasi belajar siswa yaitu dapat ditunjukkan dengan meningkatnya nilai rata-rata siswa pada setiap siklus yang terus mengalami peningkatan.

3. Aktivitas Guru dan Siswa Dalam Pembelajaran

Berdasarkan analisis data, diperoleh aktivitas siswa dalam proses pembelajaran bahasa Indonesia pada pokok bahasan berbicara dan membaca yang paling dominan adalah bekerja dengan menggunakan alat/media, mendengarkan/ memperhatikan penjelasan guru, dan diskusi antar siswa/antara siswa dengan guru. Jadi dapat dikatakan bahwa aktivitas siswa dapat dikategorikan aktif.

Sedangkan untuk aktivitas guru selama pembelajaran telah melaksanakan langah-langkah pembelajaran model STAD dan Role Playing dengan baik. Hal ini terlihat dari aktivitas guru yang muncul di antaranya aktivitas membimbing dan mengamati siswa dalam mengerjakan kegiatan LKS/menemukan konsep, menjelaskan/melatih menggunakan alat, memberi umpan balik/evaluasi/tanya jawab dimana prosentase untuk aktivitas di atas cukup besar.

\section{SIMPULAN DAN SARAN}

Dari hasil kegiatan pembelajaran yang telah dilakukan selama tiga siklus, dan berdasarkan seluruh pembahasan serta analisis yang telah dilakukan dapat disimpulkan sebagai berikut:

1. Pembelajaran dengan model STAD dan Role Playing dapat meningkatkan prestasi belajar siswa yang ditandai dengan peningkatan ketuntasan belajar siswa dalam setiap siklus, yaitu siklus I $(68,18 \%)$, siklus II $(77,27 \%)$, siklus III $(86,36 \%)$.

c. Penerapan metode pembelajaran model STAD dan Role Playing mempunyai pengaruh positif, yaitu dapat meningkatkan motivasi belajar siswa yang ditunjukan dengan hasil wawancara dengan sebagian siswa, rata-rata jawaban siswa menyatakan bahwa siswa tertarik dan berminat dengan metode pembelajaran model STAD dan Role Playing sehingga mereka menjadi termotivasi untuk belajar.

Sedangkan saran peneliti sebagai berikut:

1. Untuk melaksanakan model model STAD dan Role Playing memerlukan persiapan yang cukup matang, sehingga guru harus mampu menentukan atau memilih topik yang benar-benar bisa diterapkan dengan model model STAD dan Role Playing dalam proses belajar mengajar sehingga diperoleh hasil yang optimal.

2. Dalam rangka meningkatkan prestasi belajar siswa, guru hendaknya lebih sering melatih siswa dengan berbagai metode pembelajaran, walau dalam taraf yang sederhana, dimana siswa nantinya dapat menemukan pengetahuan baru, memperoleh konsep dan keterampilan, sehingga siswa berhasil atau mampu memecahkan masalah-masalah yang dihadapinya.

\section{UCAPAN TERIMA KASIH}

Dengan penuh rasa hormat, saya ucapkan teimakasih kepada:

1. Kepala Dinas Pendidikan Kabupaten Lombok Tengah yang telah memfasilitasi, mengizinkan penulis untk mengadakan penelitian hingga dapat terlaksana dengan baik.

2. Bapak Pengurus PGRI Kec. Pringgarata dan Ketua Gugus yang telah menfasilitasi dalam seminar hasil penelitian Guru-guru Kecamatan Pringgarata.

3. Bapak Kepala sekolah yang selalu memberi dukungan sejak awal hingga terlaksananya penelitian ini dengan baik.

4. Rekan-rekan guru yang telah memberi dukungan baik secara moral maupun tindakan langsung dalam pelaksanaan penelitian ini.

\section{DAFTAR RUJUKAN}

[1]. Arikunto, Suharsimi. 1997. Dasar-dasar Evaluasi Pendidikan. Jakarta: Bumi Aksara.

[2]. Berg, Euwe Vd. (1991). Miskonsepsi bahasa Indonesia dan Remidi Salatiga: Universitas Kristen Satya Wacana.

[3]. Hamalik, Oemar. 2002. Psikologi Belajar dan Mengajar. Bandung: Sinar Baru Algesindo.

[4]. Joyce, Bruce dan Weil, Marsh. 1972. Models of Teaching Model. Boston: A Liyn dan Bacon.

[5]. Masriyah. 1999. Analisis Butir Tes. Surabaya: Universitas Press.

[6]. Mukhlis, Abdul. (Ed). 2000. Penelitian Tindakan Kelas. Makalah Panitia Pelatihan Penulisan Karya Ilmiah untuk Guru-guru se-Kabupaten Tuban.

[7]. Nur, Moh. 2016. Pemotivasian Siswa untuk Belajar. Surabaya. University Press. Universitas Negeri Surabaya.

[8]. Soedjadi, dkk. 2000. Pedoman Penulisan dan Ujian Skripsi. Surabaya; Unesa Universitas Press. 
[9]. Suryosubroto, B. 1997. Proses Belajar Mengajar di Sekolah. Jakarta: PT. Rineksa Cipta.

[10]. Usman, Uzer. 2000. Menjadi Guru Profesional. Bandung: PT. Remaja Rosdakarya.

[11]. Widoko. 2002. Metode Pembelajaran Konsep. Surabaya: Universitas Negeri Surabaya. 